\title{
Arbuscular mycorrhizal colonization alleviates oxidative stress in tomato plants under high-temperature stress
}

\author{
Nguyen Hong DUC - Katalin POSTA \\ Szent István University, Institute of Genetics, Microbiology and Biotechnology, Department of Microbiology \\ and Environmental Toxicology, 2100 Gödöllő, Páter Károly street. 1. E-mail: hongduc.real@gmail.com
}

Keywords: arbuscular mycorrhizal fungi, oxidative stress, tomato plant, high-temperature stress

\section{Introduction}

Tomato (Solanum lycopersicum L.) is one of the most important vegetables, widely grown optimally in a range of temperature between $20^{\circ} \mathrm{C}$ and $30^{\circ} \mathrm{C}$. High-temperature stress is one of the major threats to agricultural areas around the world, depressing yield and the quality of tomato. Arbuscular mycorrhizal (AM) fungi, a ubiquitous soil microbe, can associate with the roots of most terrestrial plant species. Our objective was to study how arbuscular mycorrhizal symbiosis responds to oxidative stress in tomato plants under high-temperature stress.

\section{Materials and methods}

Solanum lycopersicum var. MoneyMaker seedlings were placed in 0.5-lit plastic pots filled with an autoclaved mixture of sand and soil $(4: 1, v / v)$. Seedlings were either inoculated with Septoglomus constrictum or non-inoculated (Control). Then, pots were distributed randomly and grown in a growth chamber (EKOCHIL 1500) at $26 / 20^{\circ} \mathrm{C}$ with $16 / 8 \mathrm{~h}$ photoperiod. After six weeks, AM and non-AM plants were put in normal conditions above and high-temperature conditions $\left(42^{\circ} \mathrm{C}\right.$ for $\left.6 \mathrm{~h}\right)$. Each treatment had ten replicates. Hydrogen peroxide accumulation (Alexieva et al., 2001), oxidative damage to lipids (Malondialdehyde) (MDA) (Heath and Packer, 1969), peroxidase (POD, EC 1.11.1.7) (Rathmell and Sequeira (1974), superoxide dismutase (SOD, EC 1.15.1.1) (Beyer and Fridovich, 1987), catalase (CAT, EC 1.11.1.6) (Aebi, 1984) activities were tested by U-2900 UV-VIS spectrophotometer (Hitachi). The soluble protein level of all extracts was determined according to the method of Bradford (1976). All data were evaluated by one-way analysis of variance (ANOVA). Means were compared by Tukey's post-hoc test at $\mathrm{P}<0.05$.

\section{Results and discussion}

Under high-temperature stress, mycorrhizal colonization significantly reduced levels of MDA and $\mathrm{H}_{2} \mathrm{O}_{2}$ in plants in comparison to non-AM plants (Figure 1). Activities of antioxidant enzymes, POD, CAT in the leaves of inoculated plants were significantly enhanced when compared to non-AM plants under high-temperature stress (Figure 2A, C). Mycorrhizal inoculation did not change enzyme SOD activity under high-temperature stress conditions (Figure 2B). 

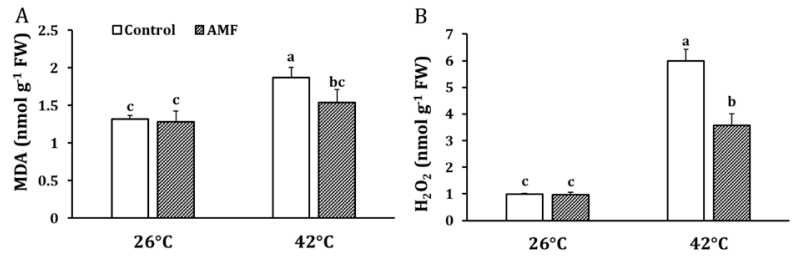

Figure 1: Malondialdehyde (MDA) (A) and $\mathrm{H}_{2} \mathrm{O}_{2}(B)$ accumulation in leaves of non-AM plants and plants inoculated by $S$. constrictum subjected to non-stress $\left(26^{\circ} \mathrm{C}\right)$, high-temperature stress $\left(42^{\circ} \mathrm{C}\right)$ conditions. Each bar represents mean \pm standard deviation $(n=4)$.
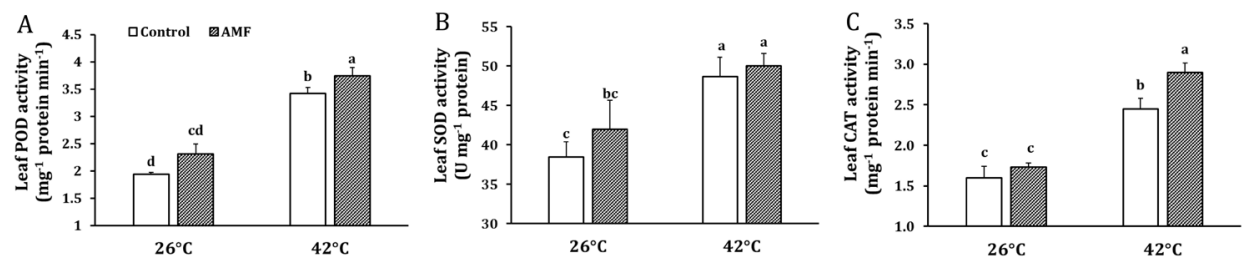

Figure 2: Activity of peroxidase (POD) (A), superoxide dismutase (SOD) (B), catalase (CAT) (C) in leaves of non-AM plants and plants inoculated by S. constrictum subjected to non-stress $\left(26^{\circ} \mathrm{C}\right)$, high-temperature stress $\left(42^{\circ} \mathrm{C}\right)$ conditions. Each bar represents mean \pm standard deviation $(n=4)$.

\section{Conclusions}

Mycorrhizal colonization could alleviate oxidative stress and enhance the effectiveness of enzymatic antioxidant systems (POD and CAT) under high temperature stress.

\section{Acknowledgement}

The authors thank to Stipendium Hungaricum fellowship for supporting this study.

\section{References}

Aebi, H. (1984): Catalase in vitro. Meth Enzymol. 105: 121-126. DOI: https://doi.org/10.1016/S00766879(84)05016-3

Alexieva, V., Sergiev, I., Mapelli, S., Karanov, E. (2001): The effect of drought and ultraviolet radiation on growth and stress markers in pea and wheat. Plant, Cell \& Environment. 24: 12. 1337-1344. DOI: https://doi. org/10.1046/j.1365-3040.2001.00778.x

Beyer, W.F., Fridovich, I. (1987): Assaying for superoxide dismutase activity: some large consequences of minor changes in conditions. Anal Biochem 161: 2. 559-566. DOI: https://doi.org/10.1016/0003-2697(87)90489-1

Bradford, M.M. (1976): A rapid and sensitive method for the quantitation of microgram quantities of protein utilizing the principle of protein-dye binding. Anal. Biochem. 72: 1-2. 248-254. DOI: https://doi. org/10.1016/0003-2697(76)90527-3

Heath, R.L., Packer, L. (1969): Photoperoxidation in isolated chloroplast, I. Kinetics and stoichiometry of fatty acid peroxidation. Arch. Biochem Biophys. 125: 1. 189-198. DOI: https://doi.org/10.1016/00039861(68)90654-1

Rathmell, W.G., Sequeira, L. (1974): Soluble peroxidase in fluid from the intercellular spaces of tobacco leaves. Plant Physiology. 53: 2. 317-318. DOI: https://doi.org/10.1104/pp.53.2.317 